ORIGINAL ARTICLE

\title{
Primary osteoarthritis and occupation in the Quebec national health and social survey
}

\section{Rossignol}

Occup Environ Med 2004;61:729-735. doi: 10.1136/oem.2003.010389

Correspondence to:

Dr M Rossignol, Montreal Department of Public Health, 1301 Sherbrooke Street East, Montreal QC, Canada H2L 1M3; mrossign@santepub-mtl. qc.ca

Accepted 12 March 2004
Background: The scientific evidence available is consistent in linking osteoarthritis (OA) and occupation but is lacking information regarding preventable risks in the workplace.

Aims: To explore the effect of different dimensions of physical demand in the relation between self reported $\mathrm{OA}$ and occupation.

Methods: Nationwide population survey of employed and self employed adults aged 25-64.

Results: Of the 11144 workers surveyed, 3.1\% (two females for one male) reported a problem with OA (any site). They reported some degree of limitations in their daily activities in a proportion that was six times higher $(26.8 \%)$ than the rest of the population of the same age without OA and twice as high for absence from work in the previous year (23.8\%). Of the different dimensions of risks used in the survey and controlling for age, body mass index, and smoking, "use of force with tools or machines" showed a statistically significant association with $\mathrm{OA}$ in males and females. In occupations significant risks of $\mathrm{OA}$ were identified in male unskilled labourers and skilled labourers, and in female technicians, and workers in the services sector.

Conclusions: Results of the present survey indicated that occupational stresses associated with OA may differ substantially between male and female workers and that specific risks may affect the younger workforce (25-44 years old) in some occupations, including housekeeping and other ill defined skilled and unskilled labour.
$\mathrm{T}$ wo systematic reviews of the relation between work and the development of osteoarthritis (OA) of the hip and knee, qualified this relation as "moderate" but consistent. ${ }^{12}$ This modest rating was partly due to the paucity of information on preventable risks in the workplace. OA is the number one cause of disability in Western populations and the potential impact of preventive measures is enormous. ${ }^{34}$ Difficulties in studying OA in occupations stem primarily from the long latency between exposure and the time when clinical and radiological manifestations occur, often long after the retirement age. Existing large population surveys have looked at established radiological OA and therefore had to estimate past occupational exposure through expert assessment. $^{5-7}$ Self reported exposure in current occupation from the Quebec Health and Social Survey, provided an opportunity to look at different dimensions of occupational risks in relation to $\mathrm{OA}$ in the active population. ${ }^{8}$

The objective of this cross sectional study was to explore the effect of different dimensions of physical demand in the workplace on the prevalence of self reported OA, in a nationwide population survey of employed and self employed adults aged $25-64$.

\section{METHODS}

The Quebec (Canada) Health and Social Survey of 1998 includes a representative cross sectional sample of the population living in private households in the province of Quebec, Canada, with the exclusion of people living on reservations or in institutions. ${ }^{9}$ The survey consisted of two waves. In the first wave, one respondent per household answered for all its members in a telephone interview. In the second wave, a mailed self administered questionnaire was sent to each member of the surveyed households. Of the 30237 participating household members, 11144 were between the age of 25 and 64 and declared themselves as being either employed or self employed.
Osteoarthritis was one of several health items on the interviewer administered questionnaire to the household respondent (first wave). The two sequential questions were: "How many members of the household have arthritis or rheumatism", and for each of them, "Is the cause related to osteoarthritis or wearing out of the joints?" There was no direct relation between the report of OA by the respondent and the declaration of joint pain in the self administered questionnaire to each household member (second wave). Therefore it was not possible to analyse hip, knee, and wrist/ hand OA separately. The representative nature of the survey of the entire population of the province of Quebec provided prevalence rates of self reported OA (all joints combined) by age and gender.

The self administered questionnaire to each household member contained a section on current occupation and occupational exposures, including risks for musculoskeletal disorders. Job titles were coded using the Canadian Standard Classification of Occupations of 1980, and then grouped in three categories according to the level of physical demandmanual, mixed, and non-manual-that had been defined in a scheme previously developed and validated. ${ }^{10}{ }^{11}$ Manual workers included skilled and unskilled blue collar workers; the mixed category included occupations involving physical work outside industrial environments such as health, education, and secretarial; and non-manual included managerial and office work. A second grouping of occupations was based on occupational sectors and included five categories: (1) professional and manager; (2) semi-professional and technician; (3) office, commerce, and services; (4) supervisor and skilled labourer; and (5) unskilled labourer.

The questions on physical demand in the workplace included: Does your current job (or one of your current jobs) expose you to: (1) handling of heavy loads like lifting or carrying persons or heavy objects such as furniture; (2) using of force with tools or machines; (3) repetitive work with the 


\section{Main messages}

- Osteoarthritis (OA) remains the principal cause of disability in the general population.

- OA also plays a significant role in work absenteeism in the active population.

- Occupational stresses to the joints contribute to the development of $\mathrm{OA}$ at ages under 40 in specific occupations.

hands and arms, such as working on a production line or feeding a machine at a fast pace; and (4) vibrations from hand tools? Each question was answered on a four point scale: never, occasionally, fairly often, and all the time. Reporting of symptoms of pain to the joints including the wrist, hip, and knee, level of physical activity, smoking, height and weight from which the body mass index was calculated (weight in $\mathrm{kg}$ divided by height in $\mathrm{m}^{2}$ ), were also obtained from the self administered questionnaire.

Associations between $\mathrm{OA}$ and occupational factors were analysed separately for males and females, in logistic regressions with self declared $\mathrm{OA}$ as the dependent variable (yes/no) and controlling for age, body mass index, and smoking. The odds ratios obtained (and their 95\% confidence intervals) provided a comparative measure of the prevalence of OA between the occupational and exposure categories.

\section{RESULTS}

Figure 1 shows general prevalence rates of self reported OA in the population. A ratio of two females for one male was observed in all age groups. The combined prevalence rates in the two younger age groups (25-44 and 45-64) represented half of those in the older population $(65+$ year old). Of the 11144 individuals employed or self employed (all age groups), 345 (3.1\%) reported a problem with OA. Among these, $53.2 \%$ declared having pain in the knee, $43.1 \%$ in the wrist or hand, and $36.4 \%$ in the hip (proportions not mutually exclusive). The onset of pain was reported to be over two years prior to the survey in $67.0 \%$. They declared being limited in their normal activities in a proportion of $26.8 \%$, which was six times higher than those of the same age group who did not report a problem with OA in the survey $(4.5 \%)$. These limitations concerned mostly (for $75.3 \%$ of them) difficulties travelling from the house to the workplace. For self reported absence from work in the previous year, workers reporting OA had over twice the rate $(23.8 \%)$ of those without OA (10.6\%) and the absences were longer,

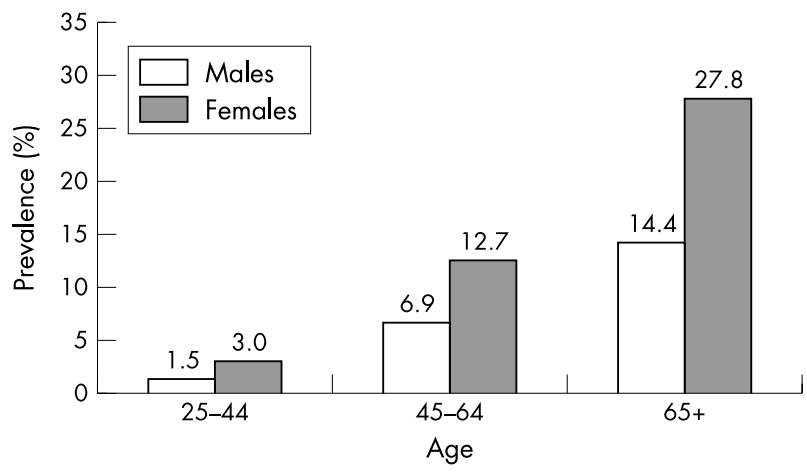

Figure 1 Prevalence rates of self declared osteoarthritis; Quebec Health and Social Survey, 1998.

\section{Policy implications}

- In specific occupations, $O A$ is not a disease of ageing, but a condition that starts early in the active life.

- Research is urgently required to identify the workers at risk and develop preventive measures to reduce the burden of $O A$.

lasting more than three weeks in $44.4 \%$ compared with $33.9 \%$ in workers without OA.

Table 1 shows the prevalence rates of $\mathrm{OA}$ in the active population aged 25-64, by occupational exposure. The response rate to the self administered occupational questionnaire was $89.2 \%$. The rates of OA in the employed population were $2.9 \%$ in males and $4.4 \%$ in females, which was less than half of those in the unemployed population of the same age, with $7.0 \%$ and $11.8 \%$ respectively (not shown in the table), differences that were statistically significant $(p<0.001)$. In males, a moderate excess in the prevalence rates was shown to be fairly uniform among the exposed in the different dimensions of physical demand; all but one were statistically different from workers not exposed. In females, there were larger variations in rates; only one reached statistical significance, the use of force with tools or machines.

The classification of occupations by type of work (manual, mixed, and non-manual) showed in males but not in females an association with OA, with a statistically significant $40 \%$ excess in manual workers compared to non-manual (OR 1.4, 95\% CI 1.1 to 1.8 ) after controlling for age, body mass index, and smoking (table 2). Of the other dimensions of physical demand of the job, only one showed consistent and statistically significant results both in males and females, the use of force with tools or machine, with $30 \%$ and $40 \%$ excess OA respectively among the exposed. In males, exposure to vibrations from hand tools and repetitive work with the arms and hands also showed associations with OA, with $40 \%$ and $30 \%$ excess OA respectively. Finally, handling

Table 1 Prevalence rates of self declared $O A$ in the active population, aged $25-64$, of respondents to the Quebec Health Survey

\begin{tabular}{|c|c|c|c|}
\hline \multirow[b]{2}{*}{ Characteristic (\% in all) } & & \multicolumn{2}{|c|}{ Prevalence rates (\%) } \\
\hline & & $\begin{array}{l}\text { Males } \\
(n=5569)\end{array}$ & $\begin{array}{l}\text { Females } \\
(n=4371)\end{array}$ \\
\hline Employed & (69.1) & $2.9 \%$ ** & $4.4 \%$ ** \\
\hline Manual work† & (32.2) & $4.1 \%$ ** & $3.8 \%$ \\
\hline Heary handling $\ddagger$ & (16.2) & $3.0 \%$ & $5.7 \%$ \\
\hline Force with tools§ & (16.8) & $3.8 \%{ }^{*}$ & $7.4 \%^{*}$ \\
\hline Repetitive motion & (18.5) & $4.3 \% *$ & $3.5 \%$ \\
\hline Vibrationst† & (8.4) & $4.4 \%^{*}$ & $6.4 \%$ \\
\hline \multicolumn{4}{|l|}{ Potential confounders } \\
\hline Excess weight¥‡ & (29.3) & $4.4 \%$ ** & $5.9 \% *$ \\
\hline Smoking§§ & (71.0) & $3.5 \%$ ** & $4.8 \%$ \\
\hline
\end{tabular}

${ }^{*} p<0.01,{ }^{* *} p<0.001 ; \chi^{2}$ test comparing the prevalence rate of $O A$ in individuals who have the characteristic to the rate of those who do not (not shown).

†Occupations classified as having regular physical demand.' †Regular handling of persons or heavy objects such as liffing and carrying.

§Regular use of force with tools or machines.

- Regular repetitive motion of hands and arms at fast pace. t†Regular exposure to vibrations from hand tools. $\ddagger \ddagger$ Body mass index $\left(\mathrm{kg} / \mathrm{m}^{2}\right) \geqslant 27$.

$\S \S$ Current regular or occasional smokers, and ex-smokers. 
Table 2 Comparison of prevalence rates of self declared $O A$ in the active population, aged 25-64, in different dimensions of occupational exposure

\begin{tabular}{|c|c|c|}
\hline & \multicolumn{2}{|c|}{ Odds ratio $(95 \% \mathrm{Cl})^{*}$} \\
\hline & Males & Females \\
\hline \multicolumn{3}{|l|}{ Manual work† } \\
\hline \multicolumn{3}{|l|}{ Handling heavy objects $\ddagger$} \\
\hline reference: none or occasional & $1.2(1.0$ to 1.4$)$ & $1.2(1.0$ to 1.5$)$ \\
\hline Use of force with tools/machines§ & $1.3(1.1$ to 1.5$)$ & $1.4(1.1$ to 1.9$)$ \\
\hline \multicolumn{3}{|l|}{ Repetitive work } \\
\hline reference: none or occasional & $1.3(1.1$ to 1.6$)$ & $0.8(0.7$ to 1.0$)$ \\
\hline Vibrations from hand tools ${ }^{* *}$ & $1.4(1.2$ to 1.7$)$ & $1.3(0.8$ to 2.1$)$ \\
\hline \multicolumn{3}{|c|}{$\begin{array}{l}\text { *Obtained from logistic regressions, adjusted for age, body mass index, and smoking. } \\
\text { tOccupations classified as having regular physical demand." } \\
\text { tRegular handling of persons or heavy objects such as lifting and carrying. } \\
\text { \$Regular use of force with tools or machines. } \\
\text { - Regular repetitive motion of hands and arms at fast pace. } \\
\text { **Regular exposure to vibrations from hand tools. }\end{array}$} \\
\hline
\end{tabular}

of heavy objects showed borderline statistical significance in males and females (95\% CI included 1.0). The different dimensions were tested separately and were not independent from one another. The correlation pattern showed that the item "use of force with tools or machines" was correlated with the item "handling of heavy objects" with a Pearson's coefficient $(r)$ of $0.58(\mathrm{p}<0.001)$, and with the item "vibrations from hand tools" with $r=0.63$ ( $\mathrm{p}<0.001)$. All other coefficients were weak, with $r<0.5$ ( $\mathrm{p}<0.001)$.

Looking at the grouping of occupations by sector, unskilled male labourers showed a prevalence of OA that was almost twice that of the reference category "professional and manager" (OR 1.8, 95\% CI 1.2 to 2.5 ) also after controlling for age, body mass index, and smoking. When restricting the analysis to the 25-44 age group, the excess reached over three times and was statistically significant (OR 3.3, 95\% CI 1.1 to 10.3). Excess prevalence of OA was also found among male skilled labourers (OR 1.7, 95\% CI 1.2 to 2.3). Females in the office, commerce, and services sector showed an excess OA that was less pronounced but statistically significant (OR 1.3, 95\% CI 1.1 to 1.8 ). With regard to the unskilled male labourer category, a stronger association was found in younger workers (OR 2.4, 95\% CI 1.4 to 4.4). Among these, there were 32 housekeepers, all females except one, with a prevalence of OA of $5.8 \%$ compared to $3.1 \%$ in the reference group. Statistically significant results were also found in the category semi-professional and technicians for the aged 2544 female workers (OR 2.0, 95\% CI 1.1 to 3.8 ).

\section{DISCUSSION}

The self reported nature of $\mathrm{OA}$ and its description and analyses as a single entity, combining all articular sites, represent the main weakness of this study and posed an important challenge to the interpretation of the results. The prevalence rates described in this study cannot be compared to those obtained in other large population surveys that used radiological or surgical criteria to define OA. However, the rates presented here were in agreement in terms of the relative distribution of OA by age and gender. ${ }^{5}$ In contrast, the Quebec Health and Social Survey offered two features that provided a unique opportunity to study the relation between $\mathrm{OA}$ and occupation: the rigorous population sampling method that was unbiased and representative of the active population, and a wealth of information on current occupational exposures obtained directly from the survey participants. This allowed the exploration of occupational risks of OA in young workers without sampling bias. In all analyses, care was taken to consider prevalence rates of $\mathrm{OA}$ for their comparative rather than absolute value, since they were obtained with identical methods in all occupational and exposure groups. Another limitation of this study was the limited availability of information on potential confounders. Body mass index and smoking, standing for other lifestyle variables, could be controlled for, but the previous history of injuries and sports/leisure activities, two other important factors controlled for in other studies, could not.'

The health and social impact of $\mathrm{OA}$ on the working population was shown to be very high, justifying the search for risk factors and preventive measures, particularly in the population that is still active and before OA becomes a rehabilitation issue. The results of this survey were consistent with the existence of an association between occupational demands and OA. As expected, the magnitude of the odds ratios was weaker than those obtained in three other large population surveys where OA patients were identified radiologically or by hospital register. ${ }^{5-7}$ Again, direct comparison is difficult because we could not distinguish between knee and hip OA as was done in those surveys, and the information on occupational exposure was obtained directly from the study subjects rather than derived from expert opinions. However, our results were consistent with previous findings regarding the risk of $\mathrm{OA}$ in housekeeping occupations and other ill defined technical and skilled labour occupations among males and females. ${ }^{7}$

This study suggests that occupational risks of OA need to be defined differently between male and female workers. The different dimensions of occupational physical demand on the joints used in this survey were all, except one, related to the prevalence of OA in males. For female workers, only the item "use of force with tools or machines" showed an association. On the other hand, associations could be found in groupings of occupation by sector, in females as much as in males. These gender differences may not only stem from different types of jobs and stresses to the joints, but also from the definitions given to physical demand in the published studies, which might have been more sensitive to jobs occupied by male than female workers. This could explain why a relatiop between OA and occupation has remained inconclusive in females. ${ }^{2}$

Given the cross-sectional nature of this population survey, the time relation between presumed exposures and OA can only be hypothesised. As OA develops, workers in specific occupations might change job or become unemployed as a result of their condition. The higher prevalence rate of OA 
Table 3 Definitions of physical demand of the job in the literature and their association with primary OA

\begin{tabular}{|c|c|c|c|c|c|}
\hline Author, year & $\begin{array}{l}\text { Site of } \\
\text { OA }\end{array}$ & $\begin{array}{l}\text { Survey population and } \\
\text { method }\end{array}$ & $\begin{array}{l}\text { Time period and unit of } \\
\text { exposure }\end{array}$ & Definition of physical demand $t$ & OR $\ddagger$ \\
\hline $\begin{array}{l}\text { Anderson JJ et al, } \\
1988^{5}\end{array}$ & Knee & $\begin{array}{l}\text { Population survey } \\
\text { HANES I } \\
x \text { ray diagnosed OA } \\
\text { Self administered } \\
\text { questionnaire }\end{array}$ & $\begin{array}{l}\text { All job titles during lifetime } \\
\text { Exposure estimated by } \\
\text { experts using job titles }\end{array}$ & $\begin{array}{l}\text { Physical demand: } \\
\text { Sedentary } \\
\text { Light work } \\
\text { Medium work } \\
\text { Heavy work } \\
\text { Very heavy work } \\
\text { Knee bending requirements: } \\
\text { None } \\
\text { Some (1-50\% of job titles) } \\
\text { Much ( } \geqslant 50 \% \text { of job titles) }\end{array}$ & OR: $3.5^{\star \star \star}$ \\
\hline $\begin{array}{l}\text { Coggon D et al, } \\
1998^{13}\end{array}$ & Hip & $\begin{array}{l}\text { Case-control study } \\
\text { Patients listed for hip } \\
\text { replacement because } \\
\text { of OA } \\
\text { Interview questionnaire }\end{array}$ & $\begin{array}{l}\text { All jobs held for longer } \\
\text { than a year since leaving } \\
\text { school and up to } 10 \text { years } \\
\text { before study } \\
\text { Maximum level of } \\
\text { exposure achieved }\end{array}$ & $\begin{array}{l}\text { Liffing: for more than } 10 \text { times in average } \\
\text { working week, for at least } 10 \text { years: } \\
<10 \mathrm{~kg} \\
10-24 \mathrm{~kg} \\
25-49 \mathrm{~kg} \\
\geqslant 50 \mathrm{~kg} \\
\text { Number of years }(0,1-9,10-19, \geqslant 20) \text { : } \\
\text { Climbing }>30 \text { flights of stairs } / \text { day } \\
\text { Walking }>2 \text { miles } / \text { day } \\
\text { Driving }>4 \mathrm{~h} / \text { day } \\
\text { Squatting }>1 \mathrm{~h} / \text { day } \\
\text { Kneeling }>1 \mathrm{~h} / \text { day } \\
\text { Standing }>2 \mathrm{~h} / \text { day } \\
\text { Sitting }>2 \mathrm{~h} / \text { day }\end{array}$ & $\begin{array}{l}\text { OR: } 2.1^{* *} \\
\text { OR: } 1.7^{* *}\end{array}$ \\
\hline $\begin{array}{l}\text { Coggon } \mathrm{D} \text { et al, } \\
2000^{14}\end{array}$ & Hip & $\begin{array}{l}\text { Case-control study } \\
\text { Patients listed for hip } \\
\text { replacement because } \\
\text { of OA } \\
\text { Interview questionnaire }\end{array}$ & $\begin{array}{l}\text { All jobs held for longer } \\
\text { than a year since leaving } \\
\text { school and up to ten } \\
\text { years before study } \\
\text { Occupational activities } \\
\text { performed for over } \\
\text { one year }\end{array}$ & $\begin{array}{l}\text { Lifting for more than } 10 \text { times in average } \\
\text { working week: } \\
\geqslant 10 \mathrm{~kg} \text {. } \\
\geqslant 25 \mathrm{~kg} \text {. } \\
\geqslant 50 \mathrm{~kg} \text {. } \\
\text { Kneeling }>1 \mathrm{~h} / \text { day } \\
\text { Squatting }>1 \mathrm{~h} / \text { day } \\
\text { Walking }>2 \text { miles } / \text { day } \\
\text { Standing or walking }>2 \mathrm{~h} / \text { day } \\
\text { Sitting }>2 \mathrm{~h} / \text { day } \\
\text { Driving }>4 \mathrm{~h} / \text { day } \\
\text { Climbing ladder or stairs }>30 \text { times/day } \\
\text { All results comparable between males } \\
\text { and females }\end{array}$ & $\begin{array}{l}\text { OR: } 1.7^{* *} \\
\text { OR: } 1.7^{* *} \\
\text { OR: } 1.8^{* *} \\
\text { OR: } 2.3^{* *} \\
\text { OR: } 1.9^{* *}\end{array}$ \\
\hline $\begin{array}{l}\text { Cooper C et al, } \\
1994^{15}\end{array}$ & Knee & $\begin{array}{l}\text { Case-control study } \\
\text { Symptomatic, } x \text { ray } \\
\text { diagnosed OA } \\
\text { Interview questionnaire }\end{array}$ & $\begin{array}{l}\text { Job held for the longest } \\
\text { time before onset of } \\
\text { symptoms } \\
\text { Exposure in an average } \\
\text { day }\end{array}$ & $\begin{array}{l}\text { Squatting }>30 \mathrm{~min} / \text { day } \\
\text { Kneeling }>30 \mathrm{~min} / \text { day } \\
\text { Stairs climbing }>10 \text { flights of stairs/day } \\
\text { Liffing weights }>25 \mathrm{~kg} \\
\text { Walking }>2 \text { miles/day } \\
\text { Standing }>2 \mathrm{~h} / \text { day } \\
\text { Sitting }>2 \mathrm{~h} / \text { day } \\
\text { Driving }>4 \mathrm{~h} / \text { day }\end{array}$ & $\begin{array}{l}\text { OR: } 6.9^{* *} \\
\text { OR: } 3.4^{* *} \\
\text { OR: } 2.7^{* *}\end{array}$ \\
\hline $\begin{array}{l}\text { Croft } P \text { et al, } \\
1992^{16}\end{array}$ & Hip & $\begin{array}{l}\text { Case-control study } \\
\text { Hip replacement or } \\
x \text { ray diagnosed OA } \\
\text { Interview questionnaire }\end{array}$ & $\begin{array}{l}\text { Lifetime occupational } \\
\text { history } \\
\text { Number of years of } \\
\text { exposure }\end{array}$ & $\begin{array}{l}\text { Duration in years: } \\
\text { Liffing weights }>25 \mathrm{~kg} \text { by hand: }<1,1-19, \\
\geqslant 20 \\
\text { Standing }>2 \mathrm{~h} / \text { day: }<20,20-39, \geqslant 40 \\
\text { Sitting }>2 \mathrm{~h} / \text { day: }<1,1-19, \geq 20 \\
\text { Bending }>2 \mathrm{~h} / \text { day: }<1,1-19, \geqslant 20 \\
\text { Kneeling }>30 \mathrm{~min} / \text { day: }<1,1-19, \geqslant 20 \\
\text { Walking }>2 \mathrm{miles} / \text { day: }<1,1-19, \geqslant 20 \\
\text { Walking rough ground }>2 \text { miles/day: } \\
<1,1-19, \geqslant 20 \\
\text { Climbing ladders: }<1,1-19, \geqslant 20 \\
\text { Squatting }>30 \mathrm{~min} / \text { day: }<1, \geqslant 1 \\
\text { Running }>1 \mathrm{~h} / \text { day: }<1, \geqslant 1 \\
\text { Climbing }>30 \text { flights stairs/day: }<1, \geqslant 1 \\
\text { Driving }>4 \mathrm{~h} / \text { day: }<1, \geqslant 1\end{array}$ & $\begin{array}{l}\text { OR: } 2.5^{* *} \\
\text { OR: } 2.7^{* * *}\end{array}$ \\
\hline $\begin{array}{l}\text { Felson DT et al, } \\
1991^{6}\end{array}$ & Knee & $\begin{array}{l}\text { Population survey } \\
\text { Framingham cohort } \\
x \text { ray diagnosed OA }\end{array}$ & $\begin{array}{l}\text { Current occupation in } \\
\text { six successive } \\
\text { questionnaires } \\
\text { (1948-61) } \\
\text { Exposure estimated by } \\
\text { experts using job titles }\end{array}$ & $\begin{array}{l}\text { Physical demand: } \\
\text { Sedentary: lifting < } 10 \mathrm{llb} \text {; occasional } \\
\text { walking-standing } \\
\text { Light: lifting <20l.; frequent lifts } 10 \mathrm{lb} \text {; frequent } \\
\text { walking-standing } \\
\text { Medium: as in "light" with lifts }<50 \mathrm{lb} \\
\text { Heavy: as in "light" with lifts }<100 \mathrm{lb} \\
\text { Very heary: as in "light" with lifts } 100+\mathrm{lb} \\
+ \text { knee bending / kneeling / crouching/crawling } \\
\text { required in job }\end{array}$ & OR: $2.4^{* *}$ \\
\hline
\end{tabular}


Table 3 Continued

\begin{tabular}{|c|c|c|c|c|c|}
\hline Author, year & $\begin{array}{l}\text { Site of } \\
\text { OA }\end{array}$ & $\begin{array}{l}\text { Survey population and } \\
\text { method }\end{array}$ & $\begin{array}{l}\text { Time period and unit of } \\
\text { exposure }\end{array}$ & Definition of physical demand $t$ & OR‡ \\
\hline $\begin{array}{l}\text { Heliovaara } M \text { et al, } \\
1993^{17}\end{array}$ & Hip & $\begin{array}{l}\text { Population survey (cohort) } \\
\text { Clinical diagnosis of OA } \\
\text { Self-administered } \\
\text { questionnaire }\end{array}$ & $\begin{array}{l}\text { Last, present or previous } \\
\text { occupation of longest } \\
\text { duration (if not the last } \\
\text { one) involving one of } \\
\text { the factors } \\
\text { Number of factors } \\
\text { (stresses) summed (0 to5) }\end{array}$ & $\begin{array}{l}\text { Lifting/carrying heavy objects } \\
\text { Stooping/twisting/awkward posture } \\
\text { Vibration whole body/equipment continuously } \\
\text { repeated series movements } \\
\text { Working speed determined by machine } \\
\text { Total number of stresses: }\end{array}$ & OR: $2.9^{* * *}$ \\
\hline $\begin{array}{l}\text { Holte } \mathrm{H} \text { et al, } \\
2000^{18}\end{array}$ & Any & $\begin{array}{l}\text { National disability } \\
\text { pensioners survey } \\
\text { Clinically diagnosed OA }\end{array}$ & $\begin{array}{l}\text { Occupation in year } \\
\text { previous to disability } \\
\text { pension } \\
\text { Physical demand coded } \\
\text { by experts }\end{array}$ & $\begin{array}{l}\text { Manual, skilled and unskilled labour (heavy } \\
\text { lifting and bending). }\end{array}$ & OR: $1.9^{* *}$ \\
\hline $\begin{array}{l}\text { Jacobsson B et al, } \\
1987^{19}\end{array}$ & Hip & $\begin{array}{l}\text { Case-control study } \\
\text { Patients on waiting list } \\
\text { for hip replacement } \\
\text { Self-administered } \\
\text { questionnaire }\end{array}$ & $\begin{array}{l}\text { Having been subjected } \\
\text { to a factor any time } \\
\text { during life (yes/no) }\end{array}$ & $\begin{array}{l}\text { Heavy labour } \\
\text { Heavy lifting } \\
\text { Much tractor driving } \\
\text { Much walking } \\
\text { Much standing }\end{array}$ & $\begin{array}{l}\text { OR: } 1.2^{*} \\
\text { OR: } 1.2^{*} \\
\text { OR: } 1.5^{*}\end{array}$ \\
\hline $\begin{array}{l}\text { Lau EC et al, } \\
2000^{20}\end{array}$ & $\begin{array}{l}\text { Hip or } \\
\text { knee }\end{array}$ & $\begin{array}{l}\text { Case-control study } \\
x \text { ray diagnosed OA } \\
\text { Interview questionnaire }\end{array}$ & $\begin{array}{l}\text { Having been engaged in } \\
\text { activities (with at least } \\
\text { one physical demand) } \\
\text { during the occupation } \\
\text { held for the longest } \\
\text { time(and at least one } \\
\text { year) before onset of } \\
\text { symptoms (yes/no) } \\
\text { No marked difference } \\
\text { between hip and knee }\end{array}$ & $\begin{array}{l}\text { Climbing } \geqslant 15 \text { flights of stairs/day } \\
\text { Lifting } \geqslant 10 \mathrm{~kg},>10 \text { times/week } \\
\text { Use vibration tools } \geqslant 1 \mathrm{~h} / \text { day } \\
\text { Walking } \geqslant 2 \mathrm{~h} / \text { day } \\
\text { Squatting } \geqslant 1 \mathrm{~h} / \text { day } \\
\text { Kneeling } \geqslant 1 \mathrm{~h} / \text { day } \\
\text { Driving } \geqslant 4 \mathrm{~h} / \text { day }\end{array}$ & $\begin{array}{l}\text { OR: } 5.1^{* *} \\
\text { OR: } 5.4^{* *} \\
\text { (No marked } \\
\text { difference } \\
\text { between hip } \\
\text { and knee) }\end{array}$ \\
\hline $\begin{array}{l}\text { Manninen } \mathrm{P} \text { et al, } \\
2002^{21}\end{array}$ & Knee & $\begin{array}{l}\text { Case-control study } \\
\text { Patients with first knee } \\
\text { arthroplasty } \\
\text { Interview questionnaire }\end{array}$ & $\begin{array}{l}\text { Cumulative exposure } \\
\text { summed for all jobs up } \\
\text { to age } 49\end{array}$ & $\begin{array}{l}\text { Physical workload : } \\
\text { Sweating/rapid heart beat: Frequent } \\
\text { Occasional } \\
\text { Not at all } \\
\text { Standing: almost all the time } \\
>\text { half of average work day } \\
<\text { half an average work day } \\
\text { Kneeling/squatting: }>4 \mathrm{~h} / \text { day } \\
2-4 \mathrm{~h} / \text { day } \\
<2 \mathrm{~h} / \text { day } \\
\text { not at all } \\
\text { Climbing: much } \\
\text { some } \\
\text { none or very little } \\
\text { Regular walking: average } \mathrm{km} / \text { week } \\
\text { Regular lifting: average weight } \times \text { no. } \\
\text { lifts/day } \\
\text { Regular driving: average } \mathrm{h} / \text { day or week }\end{array}$ & OR: $1.7^{* *}$ \\
\hline $\begin{array}{l}\text { Olsen } O \text { et al, } \\
1994^{22}\end{array}$ & Hip & $\begin{array}{l}\text { Case-control study } \\
\text { Recipients of a hip } \\
\text { prosthesis } \\
\text { Telephone interview } \\
\text { questionnaire }\end{array}$ & $\begin{array}{l}\text { Cumulative exposures } \\
\text { summed from the start } \\
\text { of the occupational } \\
\text { career to age } 49 \text { or the } \\
\text { year of OA diagnosis }\end{array}$ & $\begin{array}{l}\text { Liffing: } \mathrm{kg} / \text { week } \\
\text { Number of lifts }>40 \mathrm{~kg} / \text { week } \\
\text { Static \& dynamic work (not defined): } h / \text { week } \\
\text { Jumping : no. jumps/week }\end{array}$ & $\begin{array}{l}\text { OR: } 2.5\left(^{* * *}\right) \\
\text { OR: } 2.4\left(^{* * *}\right)\end{array}$ \\
\hline $\begin{array}{l}\text { Roach KE et al, } \\
1994^{23}\end{array}$ & Hip & $\begin{array}{l}\text { Case-control study } \\
\text { Outpatient symptomatic } \\
\text { OA } \\
\text { Self-administered } \\
\text { questionnaire }\end{array}$ & $\begin{array}{l}\text { Cumulative lifetime } \\
\text { exposure, as the sum } \\
\text { number of years exposed } \\
\text { to physical demands, on } \\
\text { average more than half } \\
\text { of their work day. } \\
\text { Individual classified } \\
\text { positive if cumulative } \\
\text { exposure greater or } \\
\text { equal to } 15 \text { years }\end{array}$ & $\begin{array}{l}\text { Heavy workload: } \\
\text { Heavy work standing } \\
\text { Work walking } \\
\text { Work kneeling/crouching } \\
\text { Light workload: if no heavy workload and: } \\
\text { Light work standing } \\
\text { Work sitting } \\
\text { Intermediate workload: all other than the } \\
\text { above }\end{array}$ & OR: $2.4^{* * *}$ \\
\hline $\begin{array}{l}\text { Sandmark } \mathrm{H} \text { et al, } \\
2000^{24}\end{array}$ & Knee & $\begin{array}{l}\text { Case-control study } \\
\text { Patients with prosthetic } \\
\text { surgery due to primary } \\
\text { tibiofemoral OA } \\
\text { Telephone interview } \\
\text { questionnaire }\end{array}$ & $\begin{array}{l}\text { Cumulative lifetime } \\
\text { exposure from age } 15 \\
\text { to } 50 \text {. Sum of duration } \\
\text { or frequency divided in } \\
\text { quartiles of exposure }\end{array}$ & $\begin{array}{l}\text { Kneeling: } h / \text { day } \\
\text { Squatting/bending: no./day } \\
\text { Jumping: no./day } \\
\text { Standing: h/day } \\
\text { Sitting: h/day } \\
\text { Whole body vibrations: h/day } \\
\text { Climbing: no. stairs/day } \\
\text { Lifting: kg } \times \text { no. lifts/day }\end{array}$ & $\begin{array}{l}\text { OR: } 1.6^{* *} \\
\text { OR: } 2.0^{* *} \\
\text { OR: } 2.0^{* * *}\end{array}$ \\
\hline
\end{tabular}


Table 3 Continued

\begin{tabular}{|c|c|c|c|c|c|}
\hline Author, year & $\begin{array}{l}\text { Site of } \\
\text { OA }\end{array}$ & $\begin{array}{l}\text { Survey population and } \\
\text { method }\end{array}$ & $\begin{array}{l}\text { Time period and unit of } \\
\text { exposure }\end{array}$ & Definition of physical demand $t$ & OR $\ddagger$ \\
\hline $\begin{array}{l}\text { Schouten JSAG } \\
\text { et al, } 1992^{25}\end{array}$ & Knee & $\begin{array}{l}\text { Population survey-cohort } \\
\text { followed for } 12 \text { years } \\
x \text { ray defined OA } \\
\text { Self-administered } \\
\text { questionnaire. }\end{array}$ & $\begin{array}{l}\text { Cumulative lifetime } \\
\text { exposure. Score } \\
\text { computed as intensity } \\
\text { (not defined) of exposure } \\
\text { times duration in years } \\
\text { summed over all jobs } \\
\text { with the exposure. } \\
\text { Scores divided in tertiles } \\
\text { (low, medium, high) }\end{array}$ & $\begin{array}{l}\text { Lifting heavy objects } \\
\text { Knocking one's knee } \\
\text { Walking } \\
\text { Standing } \\
\text { Squatting } \\
\text { Kneeling } \\
\text { Crawling }\end{array}$ & OR: $3.8^{* *}$ \\
\hline $\begin{array}{l}\text { Thelin A et al, } \\
1997^{26}\end{array}$ & Hip & $\begin{array}{l}\text { Case-control study } \\
x \text { ray diagnosed OA } \\
\text { Self-administered } \\
\text { questionnaire }\end{array}$ & $\begin{array}{l}\text { Full time working with } \\
\text { what they themselves } \\
\text { regarded as heavy } \\
\text { physical work for a } \\
\text { period longer than half } \\
\text { a year before } 16 \text { years } \\
\text { of age }\end{array}$ & Heavy physical work at young age & OR: $2.1^{*}$ \\
\hline $\begin{array}{l}\text { Vingard E et al, } \\
1991^{27}\end{array}$ & Hip & $\begin{array}{l}\text { Case-control study } \\
\text { Recipients of hip } \\
\text { prosthesis } \\
\text { Interview and self- } \\
\text { administered } \\
\text { questionnaires }\end{array}$ & $\begin{array}{l}\text { Cumulative exposure } \\
\text { calculated separately in } \\
\text { three categories: from } \\
\text { start of career to age } 29 \text {, } \\
\text { from age } 30 \text { to } 49 \text { and } \\
\text { over the age of } 49 \text {. } \\
\text { Exposure expressed as } \\
\text { summed duration or } \\
\text { frequency reported. No } \\
\text { difference between age } \\
\text { categories }\end{array}$ & $\begin{array}{l}\text { Dynamic workload (all below): } \\
\text { Lifting: } \mathrm{kg} / \text { week; } \\
\text { no. lifts }>40 \mathrm{~kg} / \text { week } \\
\text { Jumping: no. jumps/week } \\
\text { Walking with burden: h/week } \\
\text { Stairs climbing: h/week } \\
\text { Static workload (all below): } \\
\text { Standing: h/week } \\
\text { Sitting: } \mathrm{h} / \text { week } \\
\text { Biking: h/week } \\
\text { Driving: h/week } \\
\text { Twisted position: h/week }\end{array}$ & $\begin{array}{l}\text { OR: } 2.2^{* *} \\
\text { OR: } 1.8^{* *} \\
\text { OR: } 2.4^{* *} \\
\text { OR: } 2.9^{* *}\end{array}$ \\
\hline $\begin{array}{l}\text { Vingard E et al, } \\
1991^{7}\end{array}$ & $\begin{array}{l}\text { Hip or } \\
\text { knee }\end{array}$ & $\begin{array}{l}\text { Register-based } \\
\text { Population cohort study } \\
\text { Hospital care for OA }\end{array}$ & $\begin{array}{l}\text { Occupation within } 10 \\
\text { years of hospital } \\
\text { admission for OA } \\
\text { Exposure estimated by } \\
\text { experts using job titles } \\
\text { and expressed as high or } \\
\text { low dynamic or static } \\
\text { forces (not defined) acting } \\
\text { on the lower extremity }\end{array}$ & $\begin{array}{l}\text { Blue collar with dynamic forces and/or static } \\
\text { compression: } \\
\text { "High" versus "low": } \\
\text { Hip } \\
\text { Knee }\end{array}$ & $\begin{array}{l}\text { OR: } 2.2^{*} \\
\text { OR: } 1.9^{*}\end{array}$ \\
\hline $\begin{array}{l}\text { Vingard E et al, } \\
1997^{28}\end{array}$ & Hip & $\begin{array}{l}\text { Register-based case- } \\
\text { control study } \\
\text { Women who underwent } \\
\text { total hip replacement for } \\
\text { primary OA } \\
\text { Interview questionnaire }\end{array}$ & $\begin{array}{l}\text { Cumulative exposure } \\
\text { between the age of } 16 \\
\text { to } 50 \text {. Sum of duration } \\
\text { of exposure or number } \\
\text { of lifts times the weight } \\
\text { lifted in an average } \\
\text { working week. }\end{array}$ & $\begin{array}{l}\text { Sitting: h/day } \\
\text { Standing: h/day } \\
\text { Working in twisted posture: h/day } \\
\text { Lifting: } 1-5 \mathrm{~kg} \\
\quad 6-10 \mathrm{~kg} \\
\quad 11-15 \mathrm{~kg} \\
16-20 \mathrm{~kg} \\
\text { Jumping/movements between different levels: no./ } \\
\text { week } \\
\text { Climbing: no. flights of stairs/week }\end{array}$ & $\begin{array}{l}\text { OR: } 2.1^{* *} \\
\text { OR: } 2.1^{* *}\end{array}$ \\
\hline $\begin{array}{l}\text { Yoshimura } \mathrm{N} \text { et al, } \\
2000^{29}\end{array}$ & Hip & $\begin{array}{l}\text { Case-control study } \\
\text { Patients listed for total hip } \\
\text { arthroplasty due to OA } \\
\text { Interview questionnaire }\end{array}$ & $\begin{array}{l}\text { Exposure in first job } \\
\text { and main job (not } \\
\text { defined) defined as a } \\
\text { job regularly involving } \\
\text { each of the physical } \\
\text { demand (yes/no). } \\
\text { Little difference was } \\
\text { found between the } \\
\text { results on first job } \\
\text { and main job }\end{array}$ & $\begin{array}{l}\text { Lifting: } \geqslant 10 \mathrm{~kg} \text { more than once/week } \\
\quad \geqslant 25 \mathrm{~kg} \text { more than once/week } \\
\quad \geqslant 50 \mathrm{~kg} \text { more than once/week } \\
\text { Sitting } \geqslant 2 \mathrm{~h} / ? \\
\text { Standing } \geqslant 2 \mathrm{~h} / ? \\
\text { Kneeling } \geqslant 1 \mathrm{~h} / ? \\
\text { Squatting } \geqslant 1 \mathrm{~h} / ? \\
\text { Driving } \geqslant 4 \mathrm{~h} / ? \\
\text { Walking } \geqslant 3 \mathrm{~km} / ? \\
\text { Climbing } \geqslant 30 \text { flights of stairs/? }\end{array}$ & OR: $4.1^{* *}$ \\
\hline
\end{tabular}

†talicised items are those statistically significant and counted in table 4.

$\ddagger O R=$ highest odds ratios reported: *crude OR reported as statistically significant; **adjusted OR statistically significant; ***adjusted OR statistically significant, suggesting a dose-response profile.

$\left.{ }^{* * *}\right)$ As above but statistical significance not reported.

OR reported as not statistically significant are not shown in the table.

among the unemployed might result from such a phenomenon. This "healthy worker effect" would also agree with the finding of higher risks among young workers in certain occupations. Workers with early manifestations of OA would be more likely to be found in their original jobs and show a risk associated with their current occupational exposure, as described for other chronic health problems related to occupations. ${ }^{12}$
The available evidence regarding modifiable occupational risk factors associated with $\mathrm{OA}$ and its important impact on our societies, justify that OA be no longer considered a fact of ageing but a disease that should be prevented during the active life. From 1987 to 2002, we found 20 studies that reported results on the association between OA of the hip or knee and work related factors (table 3)..$^{5-7}$ 13-29 $^{-2 n l y}$ one study concerned hand or wrist OA, but no details were given on 
Table 4 Summary of definitions of physical demand of the job with a statistically significant association with $O A$

\begin{tabular}{llc}
\hline & \multicolumn{2}{l}{ Number of mentions in table 3} \\
\cline { 2 - 3 } Physical demand & $\begin{array}{l}\text { With statistically significant } \\
\text { associations with OA }\end{array}$ & Total \\
\hline Heavy workload & 11 & 11 \\
Lifting & 9 & 14 \\
Climbing & 5 & 11 \\
Jumping & 2 & 4 \\
Kneeling, squatting, bending & 7 & 19 \\
Standing & 2 & 11 \\
Driving & 1 & 9 \\
Vibrations & 0 & 1 \\
\hline
\end{tabular}

specific workplace exposures, so it was not included in table $3 .^{30}$ Survey methods included a mix of self administered and interviewer administered questionnaires. Occupational exposure was typically referred to as the average in a normal working day. The time reference for exposure varied widely from the current job to complex calculations of cumulative lifetime occupational exposure. Several studies used age cut off to consider exposure previous to OA development. Workplace factors were typically defined with specific weight (in $\mathrm{kg}$ ) parameters. Their correlation (lack of independence) was rarely reported. The odds ratios were most often adjusted for potential confounders such as sex, age, and body mass index. From those 20 studies, 10 categories of workplace factors were identified in relation to OA of the hip and knee (table 4). Squatting, kneeling, and bending were grouped together because in some studies they were defined as a single category. This latter grouping was the most often cited, but in less than half of the studies they were reported as statistically significant with regard to an association with OA (7/19). The two categories that showed the most consistent results, were physical workload and lifting, with $11 / 11$ and 9/14 mentions respectively of statistically significant results. The category physical workload was also the most often cited with reference to a dose-response relation (4/7). In this great variation of definitions of physical demand, heavy physical workload was one of the least specific and at the same time showed the strongest association with the development of primary OA in terms of consistency and dose-response effect. The lack of specification in exposure to physical demand in the workplace does not provide sufficient insight on potential preventive measures. It seems that the use of complex calculations to estimate lifetime cumulative exposure, and of age cut off, have not been successful at improving this situation.

In conclusion, the results of the present survey indicated that occupational stresses associated with OA may differ substantially between male and female workers and that specific risks may affect the younger workforce (25-44 years old) in some occupations including housekeeping and other ill defined skilled and unskilled labour. Future research should identify more precisely risks in occupations where prevalence rates were found to be high. In doing so, attention must be given to gender differences in the identification of occupational risks, and to young workers and the early manifestations of OA. Finally, specific research needs to address OA of the hand and wrist and occupations, for which the literature is almost non-existent.

\section{ACKNOWLEDGEMENTS}

The authors wish to thank Ms Nathalie Audet and Jacinthe Aubin from the Quebec Institute of Statistics for their help and support in reviewing the Quebec Health and Social Survey statistics and this manuscript.

\section{REFERENCES}

1 Lievense A, Bierma-Zeinstra S, Verhagen A, et al. Influence of work on the development of osteoarthritis of the hip: a systematic review. J Rheumatol 2001;28:2520-8.

2 Maetzel A, Makela M, Hawker G, et al. Osteoarthritis of the hip and knee and mechanical occupational exposure-a systematic overview of the evidence. $J$ Rheumatol 1997;24:1599-607.

3 World Health Organisation. The burden of musculoskeletal conditions at the start of the new millennium. WHO Technical Report Series. 919. Geneva: World Health Organisation, 2003:24-7.

4 Brooks PM. Impact of osteoarthritis on individuals and society: how much disability? Social consequences and health economic implications. Curr Opin Rheumatol 2002;14:573-7.

5 Anderson JJ, Felson DT. Factors associated with osteoarthritis of the knee in the first national health and nutrition examination survey (Hanes I). Am J Epidemiol 1988;128:179-89.

6 Felson DT, Hannan MT, Naimark A, et al. Occupational physical demands, knee bending, and knee osteoarthritis: results from the Framingham study. $J$ Rheumatol 1991;18:1587-92.

7 Vingard E, Alfredsson L, Goldie I, et al. Occupation and osteoarthrosis of the hip and knee: a register-based cohort study. Int J Epidemiol 1991;20:1025-31.

8 Rossignol M, Leclerc A, Hilliquin $\mathrm{P}$, et al. Primary osteoarthritis and occupations: a national cross-sectional survey of 10,412 symptomatic patients. Occup Environ Med 2003;60:882-6.

9 Daveluy C, Pica L, Audet N, et al. Social and health survey 1998, 2nd edn (in French). Quebec: Quebec Institute of Statistics, 2000; www.stat.gouv.qc.ca/ publications/sante/e soc-sante98.htm.

10 Statistics Canada. Standard occupational classification. Ottawa, Canada: Statistics Canada, 1981:656.

11 Hebert F, Duguay P, Massicotte P, et al. Revised occupational categories for use in descriptive studies, (in French). Montreal, Quebec: Quebec Research Institute in Occupational Health and Safety, 1995.

12 Rossignol M, Séguin P, De Guire L. Age modification of a 'healthy worker effect' on pulmonary functions from exposure to welding fumes. Am J Epidemiol 1990;132:761

13 Coggon D, Kellingray S, Inskip H, et al. Osteoarthritis of the hip and occupational lifting. Am J Epidemiol 1998;147:523-8.

14 Coggon D, Croft P, Kellingray S, et al. Occupational physical activities and osteoarthritis of the knee. Arth Rheum 2000:43:1443-9.

15 Cooper C, McAlindon T, Coggon D, et al. Occupational activity and osteoarthritis of the knee. Ann Rheum Dis 1994;53:90-3.

16 Croft P, Cooper C, Wickham C, et al. Osteoarthritis of the hip and occupational activity. Scand J Work Environ Health 1992;18:59-63.

17 Heliovaara M, Makela M, Impivaara $O$, et al. Association of overweight, trauma and workload with coxarthrosis. A health survey of 7,217 persons. Acta Orthop Scand 1993:64:513-18.

18 Holte HH, Tambs K, Bjerkedal T. Manual work as predictor for disability pensioning with osteoarthritis among the employed in Norway 1971-1990. Int J Epidemiol 2000;29:487-94.

19 Jacobsson B, Dalen N, Tjornstrand B. Coxarthrosis and labour. Int Orthop 1987;11:3111-3.

20 Lau EC, Cooper C, Lam D, et al. Factors associated with osteoarthritis of the hip and knee in Hong Kong Chinese: obesity, joint injury, and occupational activities. Am J Epidemiol 2000;152:855-62.

21 Manninen P, Keliovaara M, Riihimaki $\mathrm{H}$, et al. Physical workload and the risk of severe knee osteoarthritis. Scand J Work Environ Health 2002;28:25-32.

22 Olsen $O$, Vingard E, Koster M, et al. Etiologic fractions for physical work load, sports and overweight in the occurrence of coxarthrosis. Scand J Work Environ Health 1994;20:184-8.

23 Roach KE, Persky V, Miles T, et al. Biomechanical aspects of occupation and osteoarthritis of the hip: a case-control study. J Rheumatol 1994:21:2334-40.

24 Sandmark H, Hogstedt C, Vingard E. Primary osteoarthrosis of the knee in men and women as a result of lifelong physical load from work. Scand J Work Environ Health 2000;26:20-5.

25 Schouten JS, van den Ouweland FA, Valkenburg HA. A 12 year follow up study in the general population on prognostic factors of cartilage loss in osteoarthritis of the knee. Ann Rheum Dis 1992;51:932-7.

26 Thelin A, Jansson B, Jacobsson B, et al. Coxarthrosis and farm work: a casereferent study. Am J Ind Med 1997;32:497-501.

27 Vingard E, Hogstedt C, Alfredsson L, et al. Coxarthrosis and physical work load. Scand J Work Environ Health 1991; 17:104-9.

28 Vingard E, Alfredsson L, Malchau H. Osteoarthrosis of the hip in women and its relation to physical load at work and in the home. Ann Rheum Dis 1997;56:293-8.

29 Yoshimura N, Sasaki S, Iwasaki K, et al. Occupational lifting is associated with hip osteoarthritis: a Japanese case-control study. J Rheumatol 2000:27:434-40.

30 Caspi D, Flusser G, Farber I, et al. Clinical, radiologic, demographic, and occupational aspects of hand osteoarthritis in the elderly. Semin Arthritis Rheum 2001;30:321-31. 